\title{
ENVIRONMENTAL CONDITIONS ARE IMPORTANT INFLUENCES ON THE RECRUITMENT OF NORTH PACIFIC ALBACORE TUNA, THUNNUS ALALUNGA
}

\author{
Singh, A. A. ${ }^{1,2^{*}}-$ SAKURAmoto, K. ${ }^{2}-$ SuZUKi, N. ${ }^{2}-$ Roshni, S. ${ }^{3}-$ NAth, P. $^{1}-$ Kalla, A. ${ }^{1}$ \\ ${ }^{I}$ Department of Fisheries, College of Agriculture, Fisheries and Forestry, Fiji National \\ University, Nasinu, Fiji \\ ${ }^{2}$ Department of Ocean Science and Technology, Tokyo University of Marine Science and \\ Technology, Tokyo, Japan \\ ${ }^{3}$ Records Management Unit, Ministry of Finance, Suva, Fiji \\ (phone: +679-3-479-200; fax: +679-3-400-275) \\ *Corresponding author \\ e-mail: ajaymsp1@gmail.com \\ (Received $13^{\text {th }}$ Aug 2016; accepted $26^{\text {th }}$ Nov 2016)
}

\begin{abstract}
The effects of changing climate on numerous commercially and ecologically important fish species including the South Pacific albacore tuna, Thunnus alalunga have been documented over the past decades. The objective of this study was to explore and elucidate the relationship of environmental variables with the stock parameters of albacore tuna. The relationship of the North Pacific albacore tuna recruitment (R), female spawning stock biomass (SSB) and recruits per spawning biomass (RPS) from 1970 to 2012 with the environmental factors of sea surface temperature (SST), Pacific decadal oscillation (PDO) and El Niño southern oscillation (ENSO) was construed. SST and PDO were used as independent variables with SSB to construct stock reproduction models for R and RPS as they showed most significant relationship with the dependent variables. Model selections were based on Akaike Information Criterion (AIC) with the condition of significant parameter estimates at $p<0.05$. Models with single independent variables of SST, PDO and ENSO were also constructed to illuminate their individual effect on albacore R and RPS. From the results it can be stated that SST and PDO resulted in the most significant models for reproducing North Pacific albacore tuna R and RPS time series.
\end{abstract}

Keywords: spawning stock biomass, sea surface temperature, El Niño southern oscillation, Pacific Decadal Oscillation

\section{Introduction}

Albacore tuna is a commercially important species of tuna in the Pacific Ocean. The economy and livelihood of various Pacific Island countries and territories (PICTs) depend heavily on commercial tuna fisheries (SPC, 2012; Bell et al., 2009; Gillett, 2009). It is therefore important that fishery managers take measures to ensure the economic and biological sustainability of albacore tuna in the Pacific Ocean. Albacore tuna fishery has a long history in the Pacific Ocean; however its ecological characteristics are still not sufficiently understood. The North Pacific albacore and the South Pacific albacore are recognized as two reproductively isolated distinct stocks in the Pacific Ocean with negligible mixing (Takagi et al., 2001; Ramon and Bailey, 1996; Ueyanagi, 1969). Albacore reaches sexual maturity at around 5 years and they are mostly harvested using troll, pole-and-line and longline gears in the North Pacific where most of the fish caught range 
between 2-5 year olds (Zhang et al., 2014; Farley et al., 2014; ISC, 2014; Wells et al., 2013; Chen et al., 2012; ISC, 2011; Ueyanagi, 1957).

The Albacore Working Group of the International Scientific Committee for Tuna and Tuna-like Species (ISC) carries out stock assessments for the North Pacific albacore tuna (ISC, 2014). These assessments do not extensively analyze the influence of climatic conditions on the stock patterns and time-series trajectory. The importance of alterations in climatic conditions and their effects in structuring the ecological conditions supporting commercially important tuna species have been documented.

Changes in SST have been linked to primary productivity and albacore tuna stock dynamics in New Caledonia's EEZ (Briand, 2011). The early life stages, spatial distribution and spawning favorability of the South Pacific, North Pacific and North Atlantic albacore tuna have been shown to be related to the varying gradients of oceanic surface temperatures (Nieto et al., 2015; Lehodey et al., 2015; Dragon et al., 2015; Pearcy, 1973). Laurs et. al. (1984) studied the catch activities of the North Pacific albacore tuna off California in the summer of 1981 and established significant links between the satellite images of the SST and albacore aggregation pattern. The spawning oceanic temperature preferences for the South Pacific albacore tuna tends to be warmer surface water which occurs near the equatorial zone at the warm pool (Lehodey et al., 2008; Lehodey et al., 2015; Dragon et al., 2015) and albacore population has been projected to relocate in following the geographical movement of the preferable warm pool waters (Lehodey et al., 2011; SPC, 2012; Le Borgne et al., 2011; Ganachaud et al., 2013; Bell et al., 2013; Ganachaud et al., 2011). The effect of the warm pool SST index on the South Pacific albacore tuna stock has been demonstrated previously by Singh et al., (2015).

The negative and positive phase of the climatic variable of the Pacific decadal oscillation (PDO) has been shown to affect the recruitment stage of albacore tuna in the South Pacific (Lehodey et al., 2003). Links between the albacore tuna catch per unit effort (CPUE) and the PDO has also been established by Singh et al. (2015). Phillips et al. (2014) determined the presence of significant relationship between the PDO and SST variability and the spatial distribution of the juvenile North Pacific albacore tuna catch per unit effort (CPUE) off the United States West coast. In the South Pacific, albacore recruitment has been shown to be correlated to the El Niño Southern Oscillation (ENSO) climatic index and the related El Niño and La Niña events (Lehodey et al., 2003; Zainuddin et al., 2004). The North Pacific albacore productivity has been shown to have significant link with the dynamics of ENSO (Zhang et al., 2014).

It is evident that oceanic temperature indices and climatic conditions have substantial affect the stock parameters of albacore tuna and it needs to be elucidated in order for albacore fishery managers to be able to incorporate such effects into their management plans for the conservation and sustainability of albacore tuna stock in the Pacific. This study was undertaken to determine the effect of the SST and the environmental conditions of PDO and ENSO on the recruitment $(\mathrm{R})$, spawning stock biomass (SSB) and recruits per spawning biomass of the North Pacific albacore tuna and use those independent variables exhibiting significant correlation with the albacore tuna stock parameters to construct suitable 
models that can significantly reproduce the R and RPS trajectory of the North Pacific albacore tuna.

\section{Materials and Methods}

\section{The data}

\section{Stock data}

The albacore working group of the ISC compiles the report on the stock assessment of the North Pacific albacore tuna (Thunnus alalunga) in the North Pacific Ocean (ISC, 2014). The assessments are based on data from longline, troll, pole and line, gillnet, purse seine fishing gears as well as recreational gear, hand lines and harpoons. ISC collected catch and size composition data from its member countries of Canada, Chinese Taipei, Japan, Korea and USA including some member countries of the Western and Central Pacific Fisheries Commission (WCPFC) and Inter-American Tropical Tuna Commission (IATTC) including China. These data were used by the ISC to estimate the annual recruitment (R) and female spawning stock biomass (SSB) using the base case assessment model. The 2011 stock assessment estimated of the ISC (ISC, 2011) were independently reviewed (Chen, 2011; Cordue, 2011) and shortfalls were Identified. In addition, different studies that were conduct post-assessment (Brodziak et al., 2011; Iwata et al., 2011; Childers et al., 2011; Chen et al., 2012; Wells et al., 2013; Cosgrove et al., 2014) provided improvement on the understanding of albacore biology. These information and findings were used to conduct improved assessment of the North Pacific albacore stock by the ISC (ISC, 2014). The annual R and SSB data for albacore tuna from 1970 to 2012 was obtained from the 2014 stock assessment report, stock synthesis 3 results of the ISC (ISC, 2014).

The study area and distribution of the North Pacific albacore tuna stock falls within the geographical coordinates of $50^{\circ} \mathrm{N}-120^{\circ} \mathrm{E}, 10^{\circ} \mathrm{N}-120^{\circ} \mathrm{E}, 50^{\circ} \mathrm{N}-120^{\circ} \mathrm{W}, 10^{\circ} \mathrm{N}-$ $120^{\circ} \mathrm{W}$ as shown in Fig. 1. For this study the stock of albacore tuna within the study area in the North Pacific (Fig. 1) was treated as a distinct and reproductively isolated stock as previous work (Ichinokawa et al., 2008; Takagi et al., 2001; Ramon and Bailey, 1996; Chow and Ushiama, 1995; Suzuki et al., 1977; Ueyanagi, 1969) have shown the discreteness of this stock in comparison to the albacore tuna stock in the Southern Pacific Ocean.

The annual recruits per spawning biomass (RPS) from 1970 to 2012 was calculated from the R and SSB data. The trajectory of R, SSB and RPS are shown in Fig. 2. Also shown is the stock recruitment plot for albacore. Recruitment for each year is defined as the number fish at age-0 for that particular year. Annually, a single recruitment and single spawning period occurs based on assessments by Chen et al. (2010). The maturity ogive used for the calculation of the SSB was based on the estimation by Ueyanagi (1957) where it was determined that $50 \%$ of albacore tuna maturity occurs at age-5 and $100 \%$ at age 6 . This estimation has been used in previous assessments of albacore tuna (ISC, 2011) and also supported by recent work by Farley et al. (2014). The annual SSB for this study was the total weight of sexually mature female fish for that year. Spawning of albacore tuna occurs between the longitudes of $155^{\circ} \mathrm{W}$ and $120^{\circ} \mathrm{E}$ and between the latitudes of $10^{\circ} \mathrm{N}$ and $25^{\circ} \mathrm{N}$ (Fig. 1) between Hawaii, Taiwan and Philippine waters (Chen et al., 2010; Yoshida, 1968; Otsu and Uchida, 1959; Ueyanagi, 1957). The SSB trajectory shows a decreasing pattern from 1970 to 1993 followed by some 
recovery up to 1999 which is followed by a gradual declining pattern (Fig. 2). R has chaotic behavior throughout the years with a general declining pattern from 1971 to 1987 and a stable pattern on average up to 2012. For the RPS the trajectory exhibits a lower average from 1970 to 1988 and a distinctively higher average from 1989 to 2012.

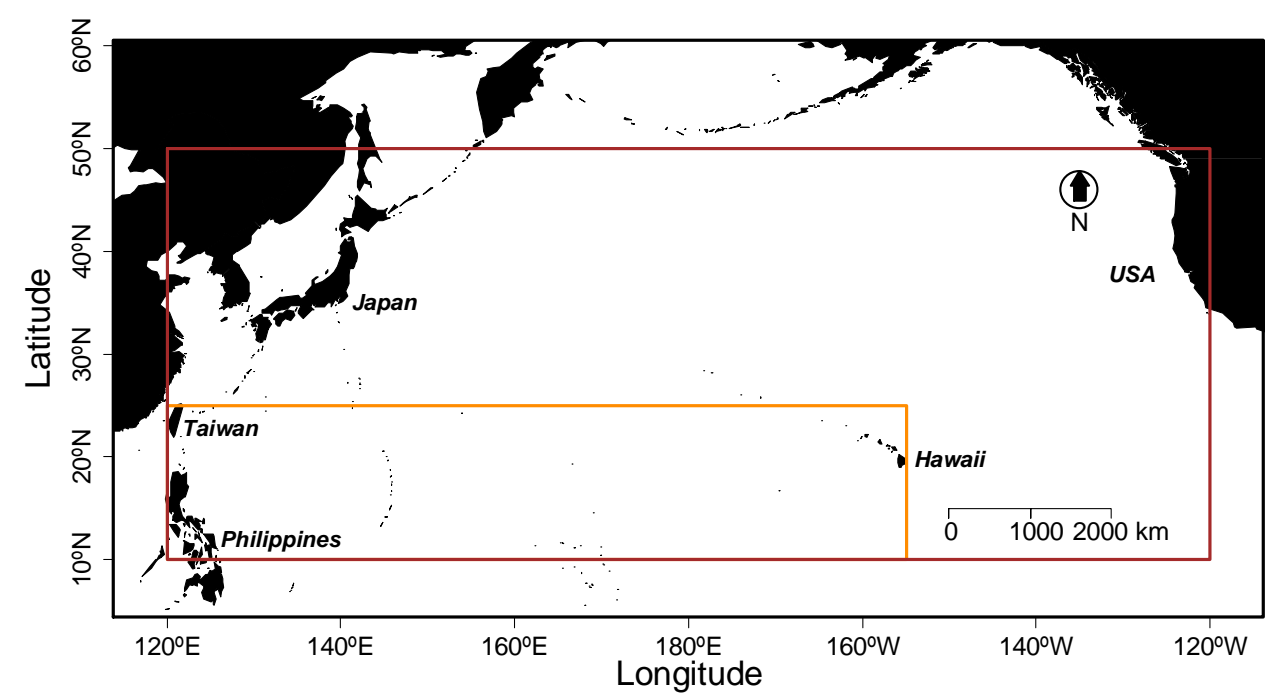

Figure 1. Map showing the recruitment and female spawning stock biomass data distribution (represented by the red enclosure box) of the albacore tuna (T. alalunga) in the North Pacific Ocean between $10^{\circ} \mathrm{N}$ to $50^{\circ} \mathrm{N}$ and $120^{\circ} \mathrm{E}$ to $120^{\circ} \mathrm{W}$ for the years 1970 to 2012 . The spawning area is also shown by the orange enclosure box as determined by Ueyanagi, (1957), Otsu and

Uchida (1959), Yoshida, (1968) and Chen et. al., (2010).
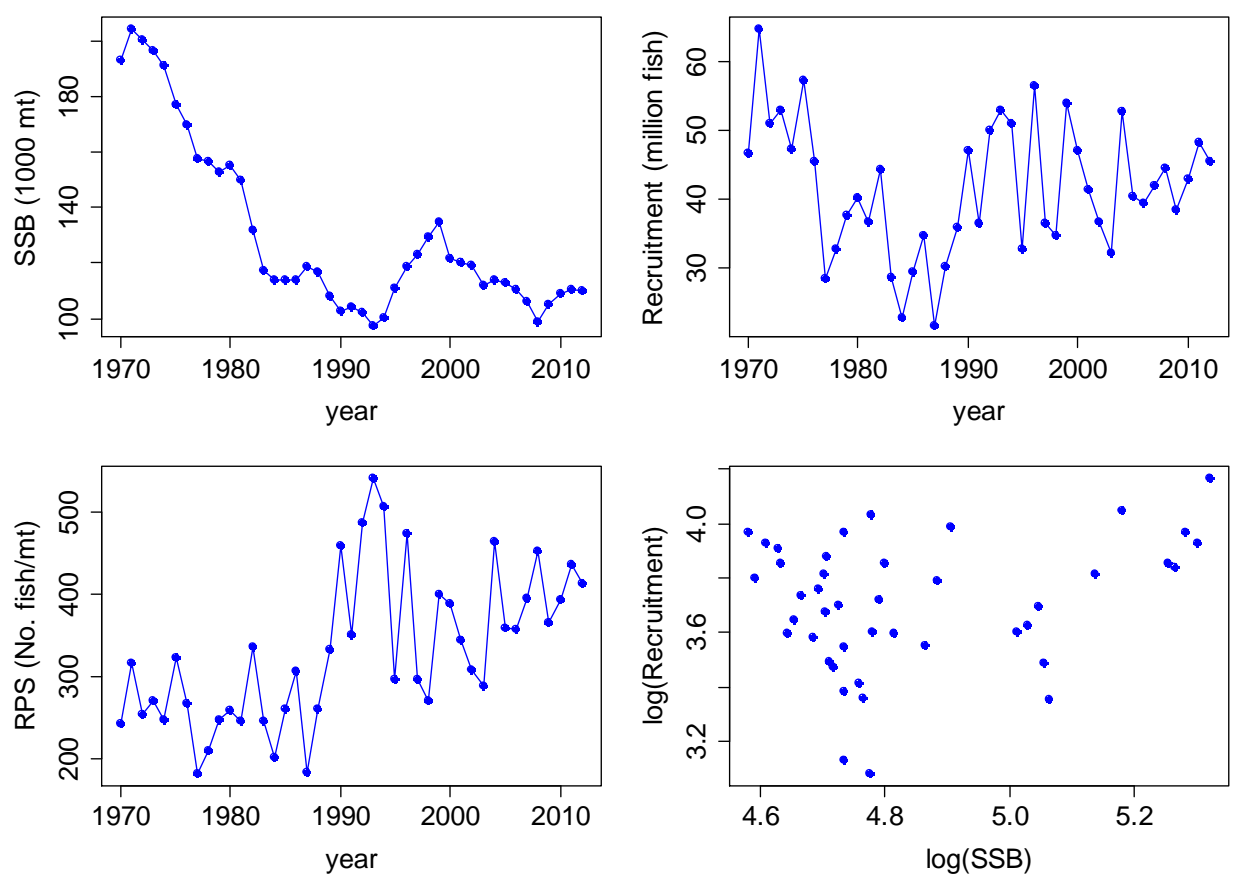

Figure 2. The recruitment (R), female spawning stock biomass (SSB) and recruits per spawning biomass (RPS) time series trajectory of the albacore tuna (T. alalunga) in the North Pacific Ocean for the years ranging from 1970-2012. Also shown is the stock recruitment scatterplot plot for albacore tuna. 


\section{Environmental data}

The mean SST observation data for the North Pacific Oceanic study area (Fig. 1) on a $1^{\circ}$ by $1^{\circ}$ resolution (Rayner et al., 2003) from 1970 to 2012 on a monthly scale from January to December was obtained from the monthly compiled Hadley Centre Sea Ice and Sea Surface Temperature data set (HadISST), complied by the Meteorological Office Hadley Center, UK. Monthly and annual SST anomalies were retrieved from this data set and the means calculated for the coordinates between $10^{\circ} \mathrm{N}$ to $50^{\circ} \mathrm{N}$ and $120^{\circ} \mathrm{E}$ to $120^{\circ} \mathrm{W}$ for the standard period of 1965 to 2012. The public domain data is available from the following link http://www.metoffice.gov.uk/hadobs/hadisst/. The detailed description of the SST dataset and its production process is decribed in Rayner et al. (2003).

The PDO is a dominant mode of climatic variability of the North Pacific oceanic surface temperature over decadal timescales (Linsley et al., 2015; Chhak et al., 2009; Deser et al., 2004; Mantua et al., 1997; Zhang et al., 1997). The Multivariate El Niño Southern Oscillation Index (ENSO) is an important climatic variability index occurring over subdecadal time scales and affecting most part of the tropics and sub-tropics. Its calculation is based on multiples variables of SST, sea-level pressure, surface air temperature, atmospheric conditions and surface wind indexes (Wolter and Timlin, 1998). The monthly climatic data from January to December from 1965 to 2012 on the PDO and ENSO was obtained from the National Oceanic and Atmospheric Administration (NOAA), Earth System Research Laboratory (ESRL), Physical Sciences Division.

\section{Exploration and comparison of variables}

Relationships between the dependent variables of R, SSB and RPS and the independent variables of SST, PDO and ENSO were determined using absolute correlations and linear regression. Correlations with $R>0.500$ at $p<0.05$ were considered as significant. R, SSB and RPS from 1970 to 2012 were compared with monthly and annual mean SST (from the raw $1^{\circ}$ by $1^{\circ}$ resolution HadISST data), PDO and ENSO from 1965 to 2012 for lag periods of $t$ - $n$ years where $n=(0,1, \ldots, 5)$. The lag periods were based on the age group of most of the harvested stock in the Pacific Ocean which ranges between 2-5 years (ISC, 2014; Wells et al., 2013; Chen et al., 2012; ISC, 2011) and albacore tuna becomes reproductively active at around 4-5 years of age (Farley et al., 2014; ISC, 2011; Ueyanagi, 1957). Data exploration for the independent and dependent variables were carried out using scatterplots, boxplots, histograms and kernel density overlays. This was used to assess data distribution and identify collinearity effects among independent variables and possible outliers which can affect the outcomes of statistical analysis and contribute to assessment bias. The data exploration protocol as outlined by Zuur et al. (2010) was followed to avoid violations of assumptions from the statistical methods utilized.

Time series data normally have two kinds of trends, stationary and stochastic. When significant changes or shocks have transitory effect, the time series is classified as having a stationary process. Trends where shocks permanently alter the trajectory are classified as stochastic trend or having a unit root. Stochastic trends can results in false correlations among variables and unit roots tests are designed to detect such trends (Kwiatkowski et al., 1992; Dickey and Fuller, 1979). The dependent variables and independent variables where subjected to MacKinnon's (MacKinnon, 1996) and the Augmented Dickey-Fuller (Dickey and Fuller, 1979) unit root tests. 


\section{Model formulation for $R$ and RPS}

Independent variables which exhibit significant correlations with the dependent variables of $\mathrm{R}$ and RPS with reference to $R$ values at $p<0.05$ were used to develop suitable stock reproduction models which can significantly reproduce the $\mathrm{R}$ and RPS trajectory for the North Pacific albacore tuna from 1970 to 2012. We attempted to explain the trajectory of the R and RPS by fitting of a stock-recruitment model to the albacore data and obtaining the Akaike Information Criterion (AIC) for each model. Similar modeling techniques have been used in previous work (Sakuramoto, 2016; Singh et al., 2014; Sakuramoto, 2013; Cahuin et al., 2009). To ease the comprehensiveness and complexity of the models, only two environmental variables were incorporated in the final models for R and RPS. The Generalized Linear Model (GLM) used for R (Equation 1) and RPS (Equation 2) are shown below

$$
\begin{aligned}
& \log \left(R_{t}\right)=\log \left(\alpha_{0, n}\right) \times \log \left(S S B_{t-n}\right)+\alpha_{1, n} \times c_{1, t-n}+\alpha_{2, n} \times c_{2, t-n}+\alpha_{3, n} \times\left(c_{1, t-n} \times c_{2, t-n}\right)+\varepsilon_{t} \\
& \log \left(R_{t} / S S B_{t}\right)=\log \left(\beta_{0, n}\right)+\beta_{1, n} \times c_{1, t-n}+\beta_{2, n} \times c_{2, t-n}+\beta_{3, n} \times\left(c_{1, t-n} \times c_{2, t-n}\right)+\varepsilon_{t}
\end{aligned}
$$

where $R$ is the albacore recruitment for year $t, \alpha_{0}$ and $\beta_{0}$ are the intercept parameters, $\alpha_{1}$, $\alpha_{2}, \alpha_{3}$ and $\beta_{1}, \beta_{2}, \beta_{3}$ are parameter estimates, $S S B$ is the albacore tuna spawning stock biomass, $c_{1}, c_{2}$ are the independent environmental variables, $R / S S B$ is the recruits per spawning biomass and $\varepsilon$ is an unsolved normally distributed random variable.

To test the non-linear responses of the predictor variables on the dependent variables the generalized additive models (GAMs) (Hastie and Tibshirani, 1986) were used. When using environmental condition as predictor variables, GAMs have frequently shown to perform better in comparison to other types of predictive modeling techniques (Drexler and Ainsworth, 2013; Moisen and Frescino, 2002; Guisan et al., 2002; Walsh and Kleiber, 2001). Second and third order polynomial functions were inserted into Equation 1 and Equation 2 to investigate if these models (GAMs) performed better. The resulting Equation 3 and Equation 4 are shown below

$$
\begin{aligned}
& \log \left(R_{t}\right)=\log \left(\gamma_{0, x, n}\right) \times \log \left(S S B_{t-n}\right)+\gamma_{1, x, n} \times c_{1, x, t-n}^{x}+\gamma_{2, x, n} \times c_{2, x, t-n}^{x}+\gamma_{3, n} \times\left(c_{1, t-n} \times c_{2, t-n}\right)+\varepsilon_{x, t} \\
& \log \left(R_{t} / S S B_{t}\right)=\log \left(\delta_{0, x, n}\right)+\delta_{1, x, n} \times c_{1, x, t-n}^{x}+\delta_{2, x, n} \times c_{2, x, t-n}^{x}+\delta_{3, n} \times\left(c_{1, t-n} \times c_{2, t-n}\right)+\varepsilon_{x, t}
\end{aligned}
$$

where $\gamma_{0}$ and $\delta_{0}$ represent the intercept parameters, $\gamma_{1}, \gamma_{2}, \gamma_{3}$ and $\delta_{1}, \delta_{2}, \delta_{3}$ are parameter estimates and $x=(1,2,3)$. The dependent variables and intercept parameter were $\log$ transformed in order to reduce the effect of possible outliers and skewness. Equations 3 and Equation 4 were used and independent environmental variables were successively incorporated and various combinations were investigated by successive elimination. Model selection was based on the AIC (Akaike, 1981) values.

All residuals for the selected models were subjected to tests for homogeneity of variance. The residual variance in all cases should be $<4.00$ or there will be significant degradation of the least square estimators (Fox, 2008) which may result in the selection of false models. The referred and estimated trajectory for albacore tuna R and RPS were plotted and compared. All statistical analysis for this study was carried out using the statistical software "R", version 3.0.1(R Core Team., 2014). 


\section{Results}

\section{Exploration and comparison of variables}

For comparison of predictor and response variables, the scatterplot matrix showing the histograms, kernel density overlays, absolute correlations and significance asterisks $\left(p<0.05^{*}, p<0.01^{* *}, p<0.001^{* * *}\right)$ are shown in Fig. 3. The relationships of the North Pacific albacore tuna R, RPS and SSB against the monthly and annual independent environmental variables of SST, PDO and ENSO with lag periods of $t$ - $n$ years are presented. Only selected independent variables and lag periods are shown based on their significance and correlations with the response variables. Months, years and lag periods not showing significant correlations with the response variables are excluded from further analysis. All three stock parameters of R, RPS and SSB exhibited significant correlation with SST, PDO and ENSO. From Fig. 3 it can be seen that R has highest correlation with $\operatorname{SST}_{a, t-2}$ for the month of April $(a)$ and the annual $(u)$ average $\operatorname{PDO}_{u, t}$. RPS had highly significant correlation with $\operatorname{SST}_{m, t-2}$ for the month of March $(m)$ and $\mathrm{PDO}_{v, t-5}$ for January (v). SSB exhibited highly significant relationship with $\mathrm{SST}_{o, t}$ for October $(o)$ and $\mathrm{PDO}_{w, t-5}$ for May $(w)$. ENSO for September $(s)$ and May had significant relationship with R and RPS but exhibited lower correlation for albacore stock parameters of R, RPS and SSB in comparison to PDO and SST (Fig. 3).To instill simplicity into the stock reproduction models only two independent environmental variables were selected for modeling.

The relationships between R and RPS and SSB and RPS are highly significant and the correlation between $\mathrm{R}$ and SSB is quite low in significance (Fig. 3). This is an indication that a signficant fraction of the $\mathrm{R}$ is not determined by SSB but other ecological factors. Fig. 4 shows the boxplots for the spread of the dependent and independent variables. All variables have quite uniform distribution except for $\mathrm{ENSO}_{s}$ and $\mathrm{ENSO}_{w}$ where possible outliers are detected; however scatterplots for $\mathrm{ENSO}_{\mathrm{s}}$ and $\mathrm{ENSO}_{w}$ do not show any points that are abnormally large or small. Based on this argument, we accept that the likelihood of observation or process errors in the dependent and independent variables are prominently minimized.

When statistical techniques such as simple linear regression are used, there is a tendency for spurious correlations to arise due to the presence of a unit root in time series data. Unit roots tests are techniques to detect such cases (MacKinnon, 1996; Kwiatkowski et al., 1992; Dickey and Fuller, 1979). The results of MacKinnon's (Mtest) and the Augmented Dickey-Fuller (ADF-test) unit root test for the dependent and independent variables are shown in Table 1. All the time series data should have a t-test value (t-value) of $<0$ at $p<0.05$ to have a stationary process and the correlation results to be authentic. M-test and ADF-test showed that all variables exhibited stationarity (Table 1) and did not have unit root processes.

\section{Model formulation for $R$ and $R P S$}

The most significant stock reproduction models for the albacore tuna R and RPS are shown in Table 2. Model significance was taken with reference to the AIC resulting from the incorporation of the independent variable of SST and PDO into Equation 3 and Equation 4. Modeling results from single independent variable using Equation 3 and Equation 4 are also shown in Table 2. Model (i) is the most significant for albacore tuna $\mathrm{R}$ and incorporates the independent variables of $\mathrm{SST}_{a, t-2}$ and $\mathrm{PDO}_{u, t}$. For RPS model (v) the most significant and has the independent variables of $\mathrm{SST}_{m, t-2}$ and $\mathrm{PDO}_{v, t-5}$. For the 
models with single independent variables for $\mathrm{R}$, all models are significant with the model incorporating $\mathrm{SST}_{a, t-2}$ being the most significant followed by $\mathrm{PDO}_{u, t}$ and $\mathrm{ENSO}_{s, t-}$ ${ }_{1}$. For the RPS all models with single independent variables are significant with the most significant model incorporating $\mathrm{SST}_{m, t-2}$ followed by $\mathrm{PDO}_{v, t-5}$ and $\mathrm{ENSO}_{w, t-2}$.
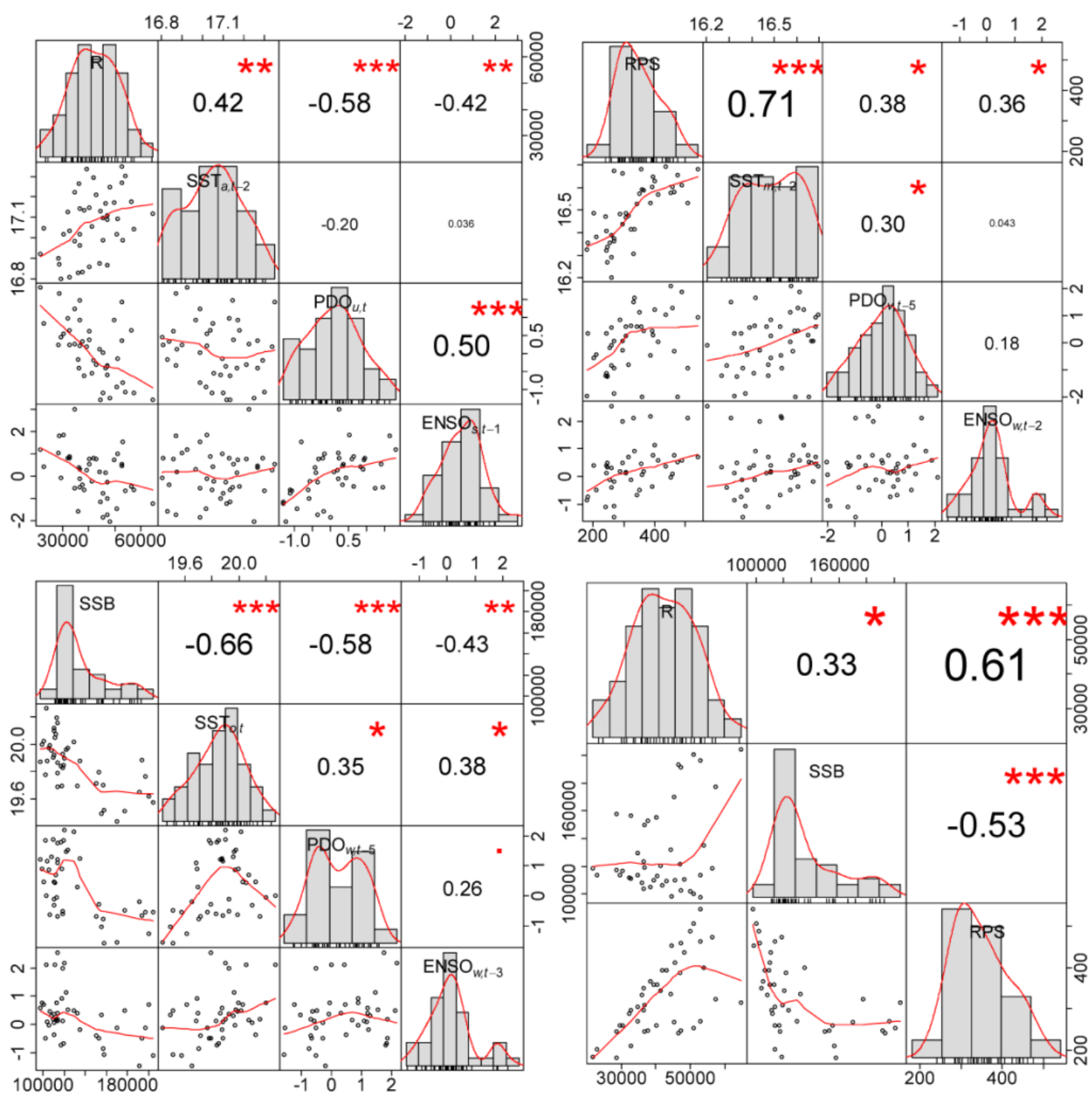

Figure 3. Scatterplot matrix showing histograms, kernel density overlays, absolute correlations and significance asterisks $\left(p<0.05^{*}, p<0.01 * *, p<0.001^{* * *}\right)$ for the relationship of North Pacific albacore tuna (T. alalunga) recruitment $(R)$, recruits per spawning biomass $(R P S)$ and female spawning stock biomass (SSB) against the environmental variables of sea surface temperature (SST), Pacific decadal oscillation (PDO) and El Niño southern oscillation (ENSO). The relationship between $R, R P S$ and SSB can also be observed. Correlations are significant at $p<0.05$. 


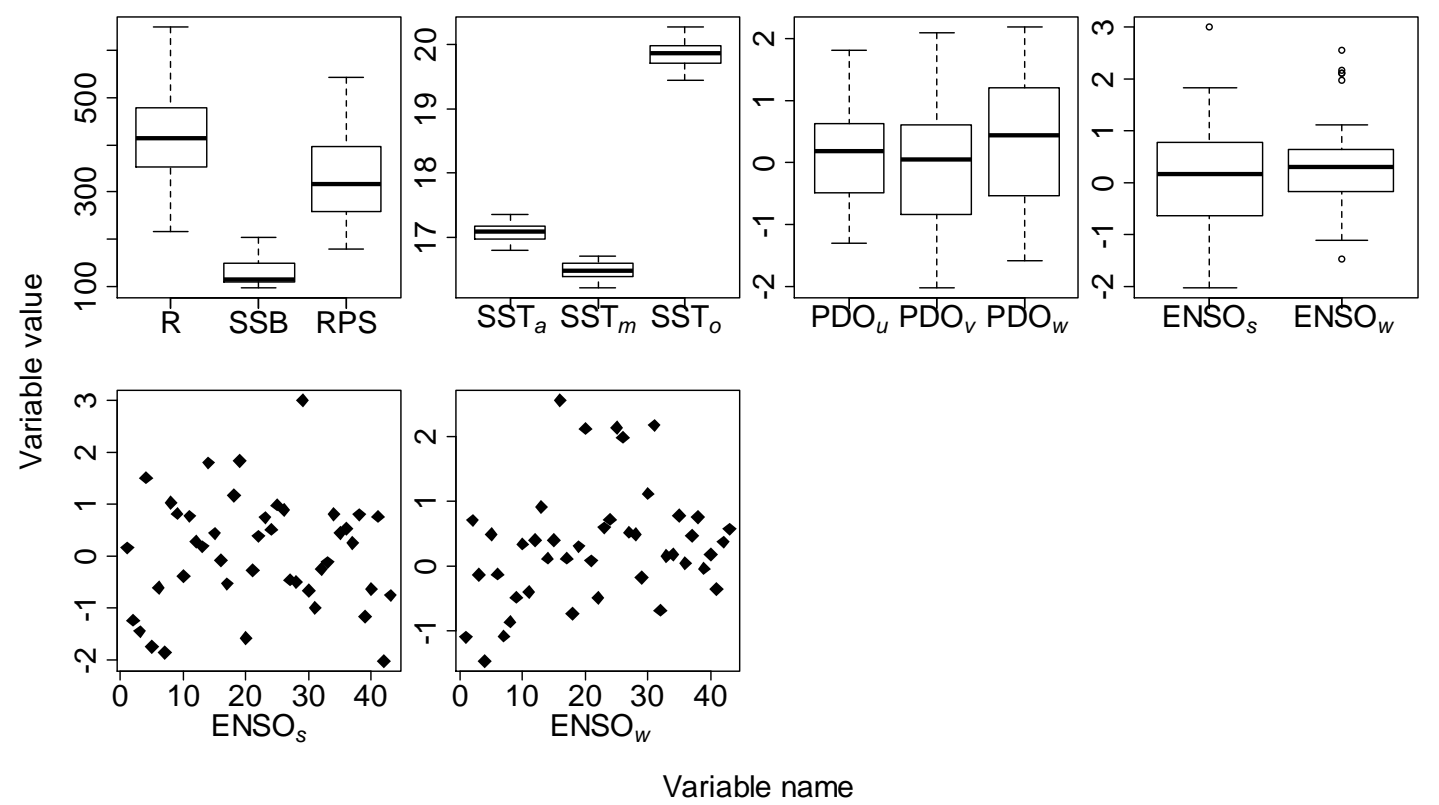

Figure 4. Boxplots for the North Pacific albacore tuna (T. alalunga) stock variables and environmental variables showing the spread of the data. The median is represented by the line in the middle of the boxes. Scatter plots further show the distribution of El Niño southern oscillation (ENSO) data to detect for the presence of outliers. The subscripts refer to the months and annual averages with: $v$-January, $m$-March, $a$-April, w-May, $s$-September, oOctober, u-annual.

Table 1. Unit root test results for dependent and independent variables time series used in correlation analysis from Fig. 3. The subscripts refer to the months, annual averages and lag periods with: $v$-January, $m-$ March, $a-$ April, $w-$ May, $s-$ September, o-October, $u$ - annual.

\begin{tabular}{ccccc}
\hline Time series & \multicolumn{2}{c}{ M-test } & \multicolumn{2}{c}{ ADF-test } \\
\hline & t-value & $p$-value & t-value & $p$-value \\
\hline $\mathrm{R}_{t}$ & -9.440 & $1.28 \times 10^{-11}$ & -9.439 & $<1.00 \times 10^{-2}$ \\
$\mathrm{SSB}_{t}$ & -4.329 & $1.01 \times 10^{-4}$ & -4.329 & $<1.00 \times 10^{-2}$ \\
$\mathrm{RPS}_{t}$ & -9.243 & $2.27 \times 10^{-11}$ & -9.243 & $<1.00 \times 10^{-2}$ \\
$\mathrm{SST}_{a, t-2}$ & -9.213 & $2.47 \times 10^{-11}$ & -9.213 & $<1.00 \times 10^{-2}$ \\
$\mathrm{SST}_{m, t-2}$ & -10.561 & $5.34 \times 10^{-13}$ & -10.560 & $<1.00 \times 10^{-2}$ \\
$\mathrm{SST}_{o, t}$ & -8.081 & $7.38 \times 10^{-10}$ & -8.081 & $<1.00 \times 10^{-2}$ \\
$\mathrm{PDO}_{u, t}$ & -7.803 & $1.74 \times 10^{-9}$ & -7.803 & $<1.00 \times 10^{-2}$ \\
$\mathrm{PDO}_{v, t-5}$ & -10.035 & $2.32 \times 10^{-12}$ & -10.035 & $<1.00 \times 10^{-2}$ \\
$\mathrm{PDO}_{w, t-5}$ & -7.927 & $1.18 \times 10^{-9}$ & -7.928 & $<1.00 \times 10^{-2}$ \\
$\mathrm{ENSO}_{s, t-1}$ & -10.569 & $5.22 \times 10^{-13}$ & -10.569 & $<1.00 \times 10^{-2}$ \\
$\mathrm{ENSO}_{w, t-2}$ & -8.653 & $1.30 \times 10^{-10}$ & -8.653 & $<1.00 \times 10^{-2}$ \\
$\mathrm{ENSO}_{w, t-3}$ & -8.589 & $1.58 \times 10^{-10}$ & -8.589 & $<1.00 \times 10^{-2}$ \\
\hline
\end{tabular}

Fig. 5 shows the plot of the predicted R from model (i) (Table 2) and the referred $\mathrm{R}$ for the North Pacific albacore tuna. The referred RPS and predicted RPS from model (v) can also be observed. In both cases the predicted and referred trajectories seem to fit well. Fig. 6 shows the trajectories of predicted R using single independent variables from models (ii), (iii) and (iv) (Table 2) and the referred R. Model (ii) with SST seems 
to be the best fit followed by model (iii) with PDO and model iv with ENSO. The trajectories for the predicted RPS from models (vi), (vii) and (viii) (Table 2) using single variables with the referred RPS are shown in Fig. 7. Model (vi) with SST is the best fit followed by model (vii) with PDO and model (viii) with ENSO.

The linear correlation between the predicted R from models (i)-(iv) and referred $\mathrm{R}$ and predicted RPS from models (v)-(viii) against referred RPS is shown in Fig. 8. The correlation between $\mathrm{R}$ predicted and R referred and RPS predicted and RPS referred is significantly higher for models incorporating two environmental variables (models (i) and (iv)) compared to using single variables. For models with single variables, SST and PDO result in models with higher significance compared to ENSO. This justifies the incorporation of the SST and PDO in the final models (models (i) and (iv)).

Table 2. Stock reproduction models and some parameters using the female spawning stock biomass (SSB) and the independent environmental variables from Fig. 3 for the albacore tuna (T. alalunga) recruitment $(R)$ and recruits per spawning biomass (RPS) in the North Pacific Ocean. Models using single variables are also shown. Only Models with highest significance are shown in each case with reference to the Akaike information criterion (AIC) values. The subscripts refer to the months, annual averages and lag periods with: $v-$ January, $m$-March, a-April, $w$-May, s-September, o-October, $u$-annual.

\begin{tabular}{|c|c|c|c|c|c|}
\hline \multicolumn{6}{|c|}{$\begin{array}{c}\text { Recruitment } \\
\text { Model with multiple variables }\end{array}$} \\
\hline i.) & $\begin{array}{l}\log \left(R_{t}\right)=1.284 \times \log \left(S S B_{t}\right)+0.450 \times S S T_{Q, t-2}-11.423 \times P D O_{u, t}+0.661 \times\left(S S T_{Q, i t-2} \times\right. \\
\left.P D D_{u, t}\right)\end{array}$ & $\begin{array}{l}\text { t-value } \\
\text { F statistic } \\
\text { DF }\end{array}$ & $\begin{array}{l}7.945 \\
63.12 \\
41\end{array}$ & $\begin{array}{l}p \text {-value } \\
R^{2} \\
\text { AIC }\end{array}$ & $\begin{array}{l}1.41 \times 10^{-10} \\
0.606 \\
875\end{array}$ \\
\hline \multicolumn{6}{|c|}{ Models with single variables } \\
\hline ii.) & $\log \left(R_{t}\right)=1.610 \times \log \left(55 B_{t}\right)+1.01 \times 10^{-2} \times 55 T_{0, t-2}^{2}$ & $\begin{array}{l}\text { t-value } \\
\text { F statistic } \\
\text { DF }\end{array}$ & $\begin{array}{l}5.298 \\
28.07 \\
41\end{array}$ & $\begin{array}{l}p \text {-value } \\
R^{2} \\
\text { AIC }\end{array}$ & $\begin{array}{l}4.28 \times 10^{-6} \\
0.406 \\
893\end{array}$ \\
\hline iii.) & $\log \left(R_{\mathrm{t}}\right)=2.467 \times \log \left(S S E_{\mathrm{z}}\right)-0.106 \times P D O_{\mathrm{u} t}$ & $\begin{array}{l}\text { t-value } \\
\text { F statistic } \\
\text { DF }\end{array}$ & $\begin{array}{l}3.556 \\
12.65 \\
41\end{array}$ & $\begin{array}{l}p \text {-value } \\
R^{2} \\
\text { AIC }\end{array}$ & $\begin{array}{l}9.65 \times 10^{-4} \\
0.236 \\
904\end{array}$ \\
\hline iv.) & $\log \left(R_{t}\right)=2.466 \times \log \left(S S B_{t}\right)-6.25 \times 10^{-2} \times E N S O_{s t-1}$ & $\begin{array}{l}\text { t-value } \\
\text { F statistic } \\
\text { DF }\end{array}$ & $\begin{array}{l}2.935 \\
8.616 \\
41\end{array}$ & $\begin{array}{l}p \text {-value } \\
R^{2} \\
\text { AIC }\end{array}$ & $\begin{array}{l}5.44 \times 10^{-3} \\
0.174 \\
907\end{array}$ \\
\hline \multicolumn{6}{|c|}{$\begin{array}{c}\text { Recruits per spawning biomass (RPS) } \\
\text { Model with multiple variables }\end{array}$} \\
\hline v.) & 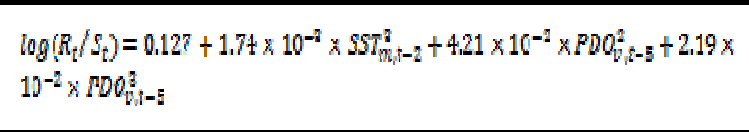 & $\begin{array}{l}\text { t-value } \\
\text { F statistic } \\
\text { DF }\end{array}$ & $\begin{array}{l}7.620 \\
58.06 \\
41\end{array}$ & $\begin{array}{l}p \text {-value } \\
R^{2} \\
\text { AIC }\end{array}$ & $\begin{array}{l}2.23 \times 10^{-9} \\
0.586 \\
478\end{array}$ \\
\hline \multicolumn{6}{|c|}{ Models with single variables } \\
\hline vi.) & $\log \left(R_{\mathrm{t}} / S_{\mathrm{t}}\right)=5.64 \times 10^{-9}+1.50 \times S S T_{m, \mathrm{t}-2}$ & $\begin{array}{l}\text { t-value } \\
\text { F statistic } \\
\text { DF }\end{array}$ & $\begin{array}{l}6.481 \\
42.01 \\
41\end{array}$ & $\begin{array}{l}p \text {-value } \\
R^{2} \\
\text { AIC }\end{array}$ & $\begin{array}{l}8.94 \times 10^{-8} \\
0.506 \\
486\end{array}$ \\
\hline vii.) & $\log \left(R_{t} / s_{t}\right)=301.21+0.115 \times F D D_{v t-5}+5.01 \times 10^{-2} \times P D D_{v-5}^{2}$ & $\begin{array}{l}\text { t-value } \\
\text { F statistic } \\
\text { DF }\end{array}$ & $\begin{array}{l}3.293 \\
10.84 \\
41\end{array}$ & $\begin{array}{l}p \text {-value } \\
R^{2} \\
\text { AIC }\end{array}$ & $\begin{array}{l}2.05 \times 10^{-3} \\
0.209 \\
506\end{array}$ \\
\hline viii & $\log \left(R_{t} / s_{t}\right)=307.96+0.280 \times E N 5 O_{W, t-2}-4.67 \times 10^{-2} \times E N 50_{W:-2}^{2}$ & $\begin{array}{l}\text { t-value } \\
\text { F statistic } \\
\text { DF }\end{array}$ & $\begin{array}{l}3.055 \\
9.34 \\
41\end{array}$ & $\begin{array}{l}p \text {-value } \\
R^{2} \\
\text { AIC }\end{array}$ & $\begin{array}{l}3.94 \times 10^{-3} \\
0.186 \\
507\end{array}$ \\
\hline
\end{tabular}



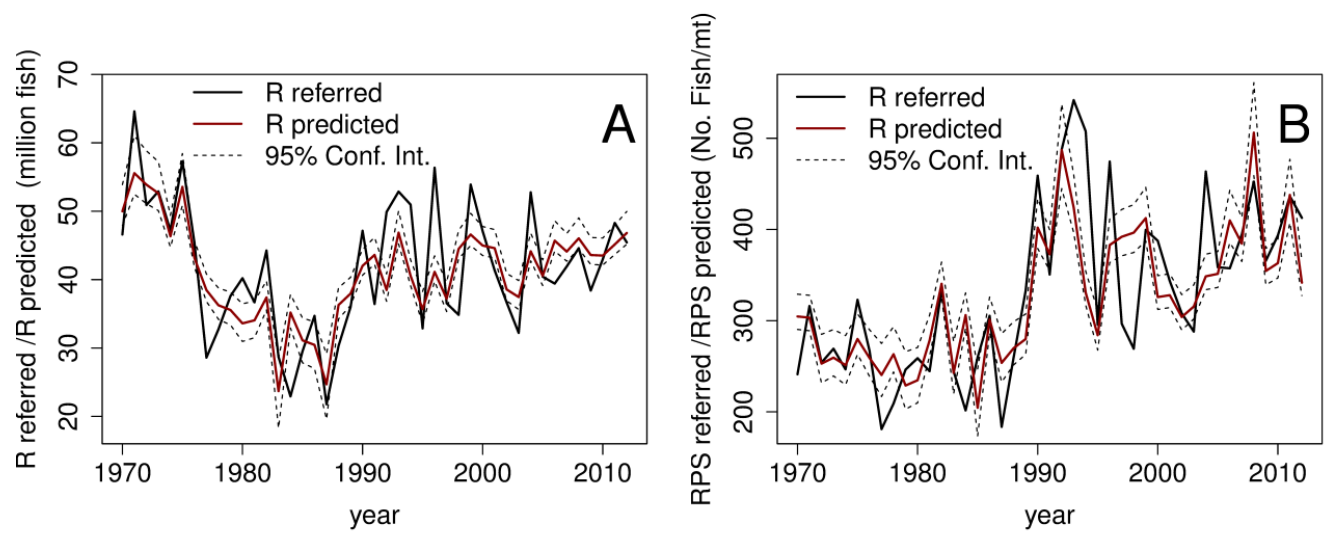

Figure 5. Key model plots showing; $(A)$ the referred and the predicted recruitment $(R)$ from model $(i)($ Table 2$)$ and $(B)$ the referred and predicted recruits per spawning biomass (RPS) from model ( $v)$ (Table 2) time series trajectory of the North Pacific albacore tuna (T. alalunga) stock from 1970-2012. The 95\% confidence interval for the estimated $R$ and RPS are shown.

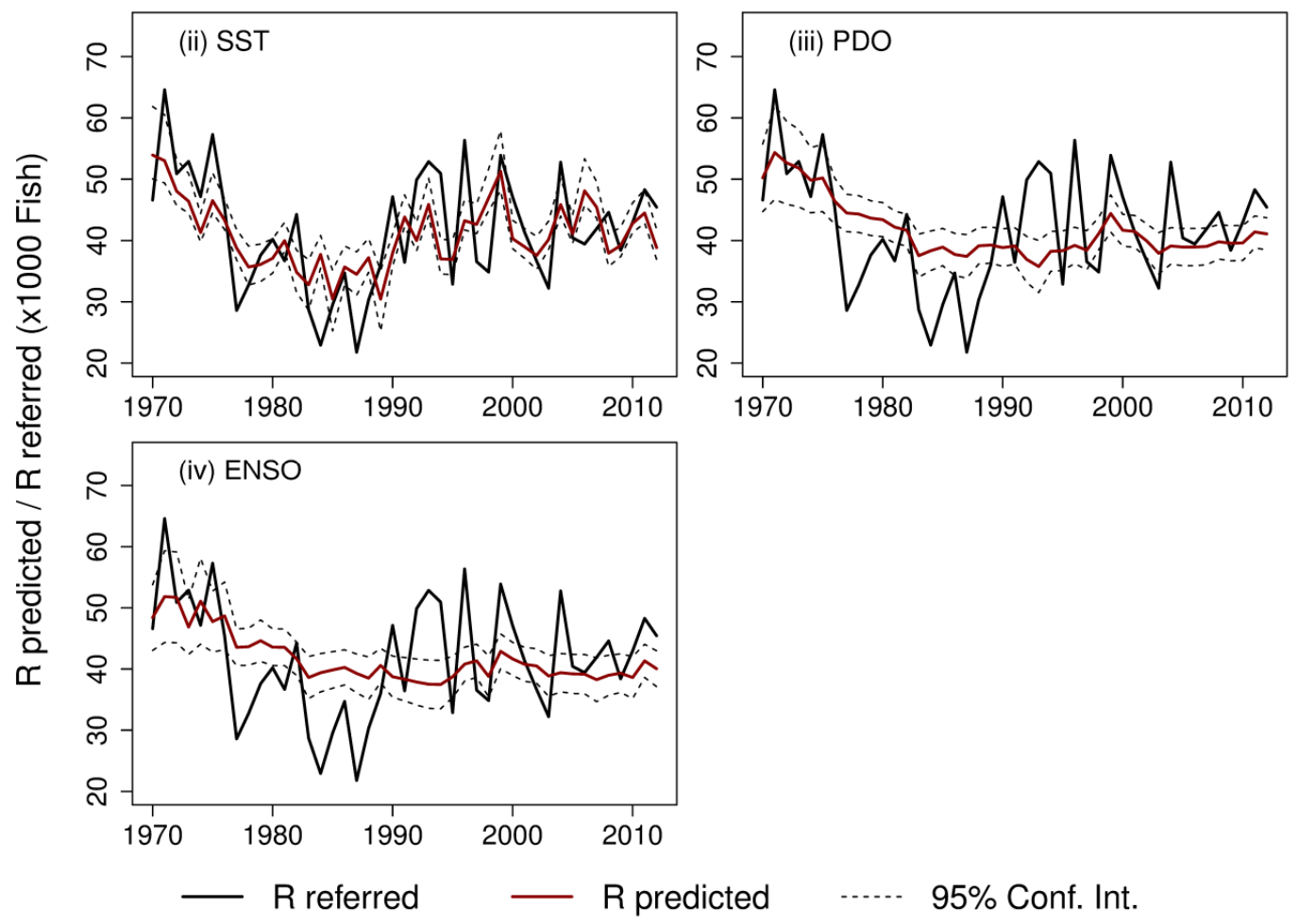

Figure 6. Graph showing the referred recruitment $(R)$ time series trajectory of the North Pacific albacore tuna (T. alalunga) stock and the trajectory which resulted from models with single variables of sea surface temperature (SST), Pacific decadal oscillation (PDO) and El Niño southern oscillation (ENSO) for the years 1970-2012. The 95\% confidence interval for the estimated R and RPS are also shown. The roman numerals refer to the models from Table 2. 


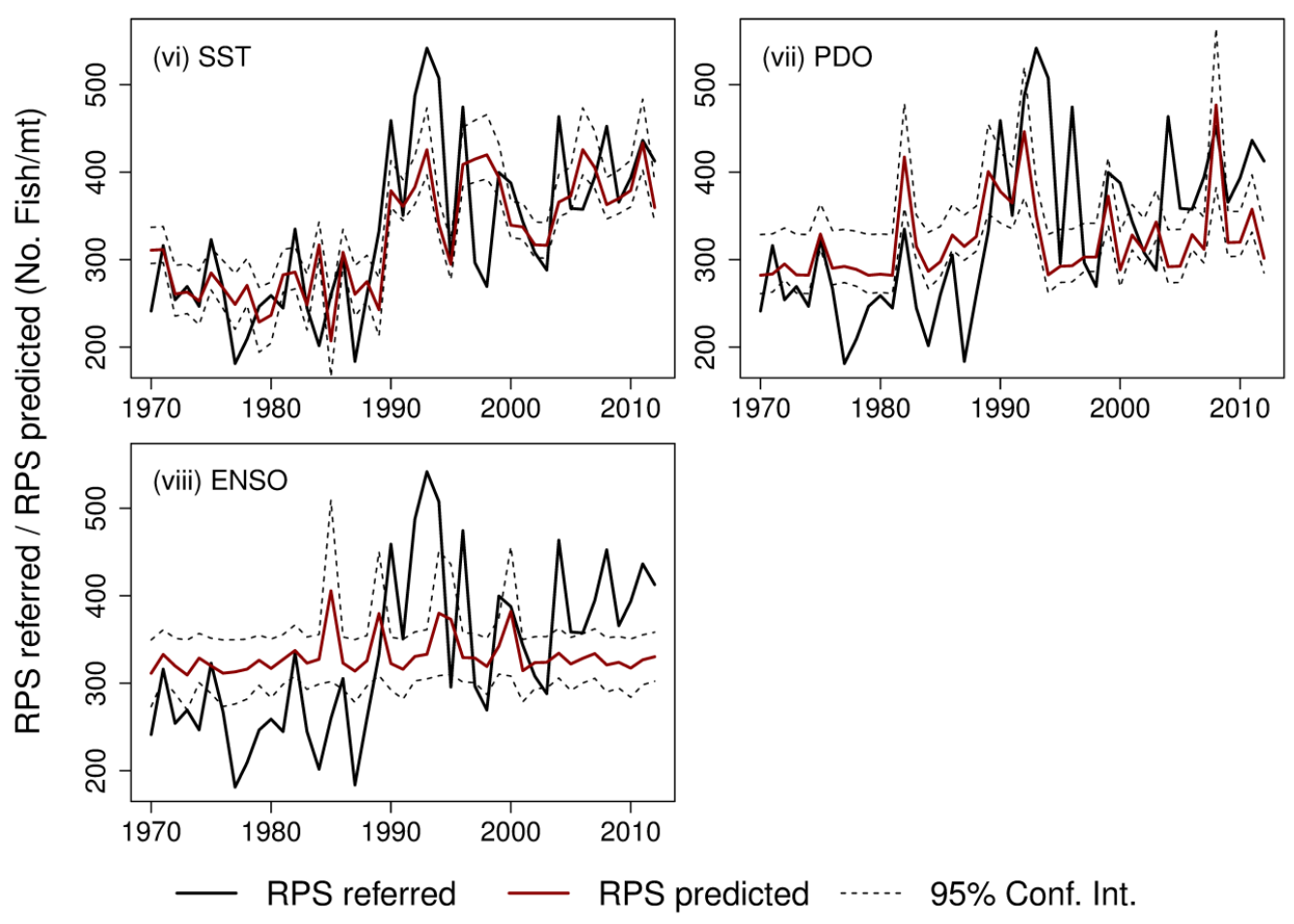

Figure 7. Graph showing the referred recruits per spawning biomass (RPS) time series trajectory of the North Pacific albacore tuna (T. alalunga) stock and the trajectory which resulted from models with single variables of sea surface temperature (SST), Pacific decadal oscillation (PDO) and El Niño southern oscillation (ENSO) in red for the years 1970-2012. The 95\% confidence interval for the estimated $R$ and RPS are also shown. The roman numerals refer to the models from Table 2.

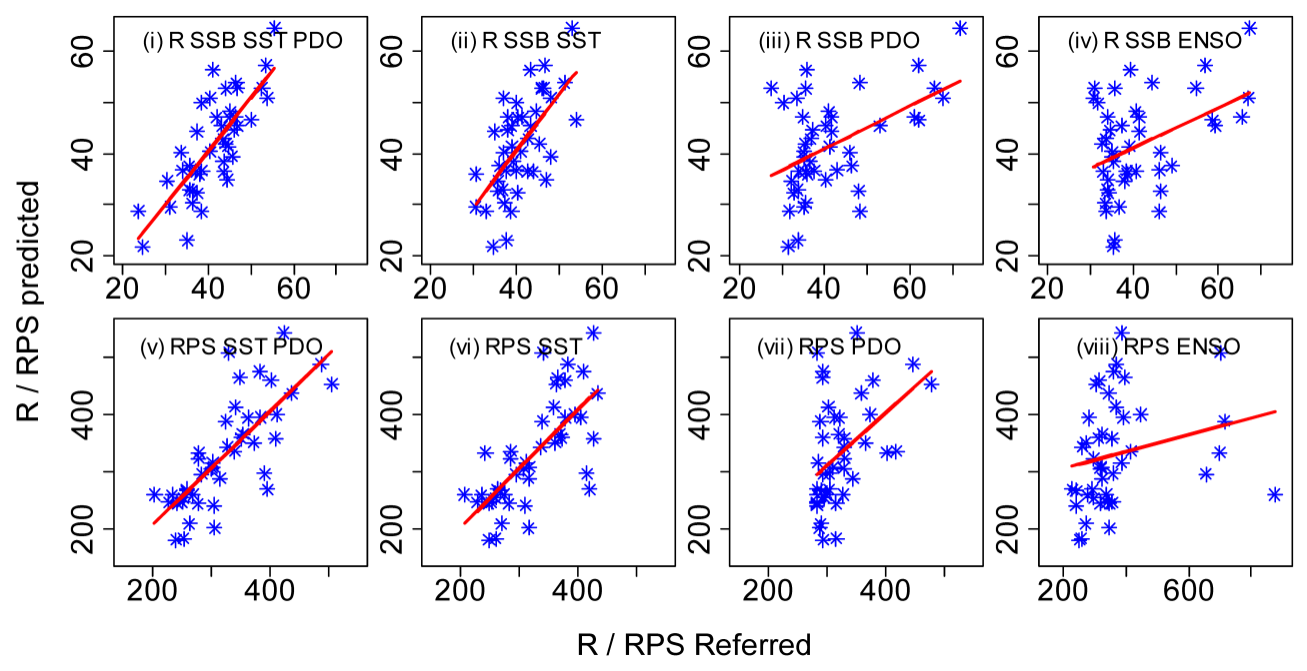

Figure 8. The linear relationship between the predicted recruitment ( $R$ predicted) and referred recruitment ( $R$ referred) ( $i$, ii, iii, $i v)$ and recruits per spawning biomass predicted (RPS predicted) and recruits per spawning biomass referred (RPS referred) ( $v$, vi, vii, viii) for the albacore tuna (T. alalunga) stock in the North Pacific Ocean. The roman numerals refer to the model numbers presented in Table 2. Axis values are same for all figures for R and RPS except for (viii) where some extreme values can be observed. 
The histograms for the residuals of models (i)-(viii) from Table 2 are shown in Fig. 9 to test for the homogeneity of variance. If the model residual variance is $>4.00$ then the least square estimators will be considerably degraded and this can lead to the selection of erroneous models (Fox, 2008). Models (i)-(iv) for R had residual variances of $<0.9$ and for RPS the models (v)-(viii) had residual variance values of $<1.2$ in all cases which fulfilled the requirements for the homogeneity of variance.

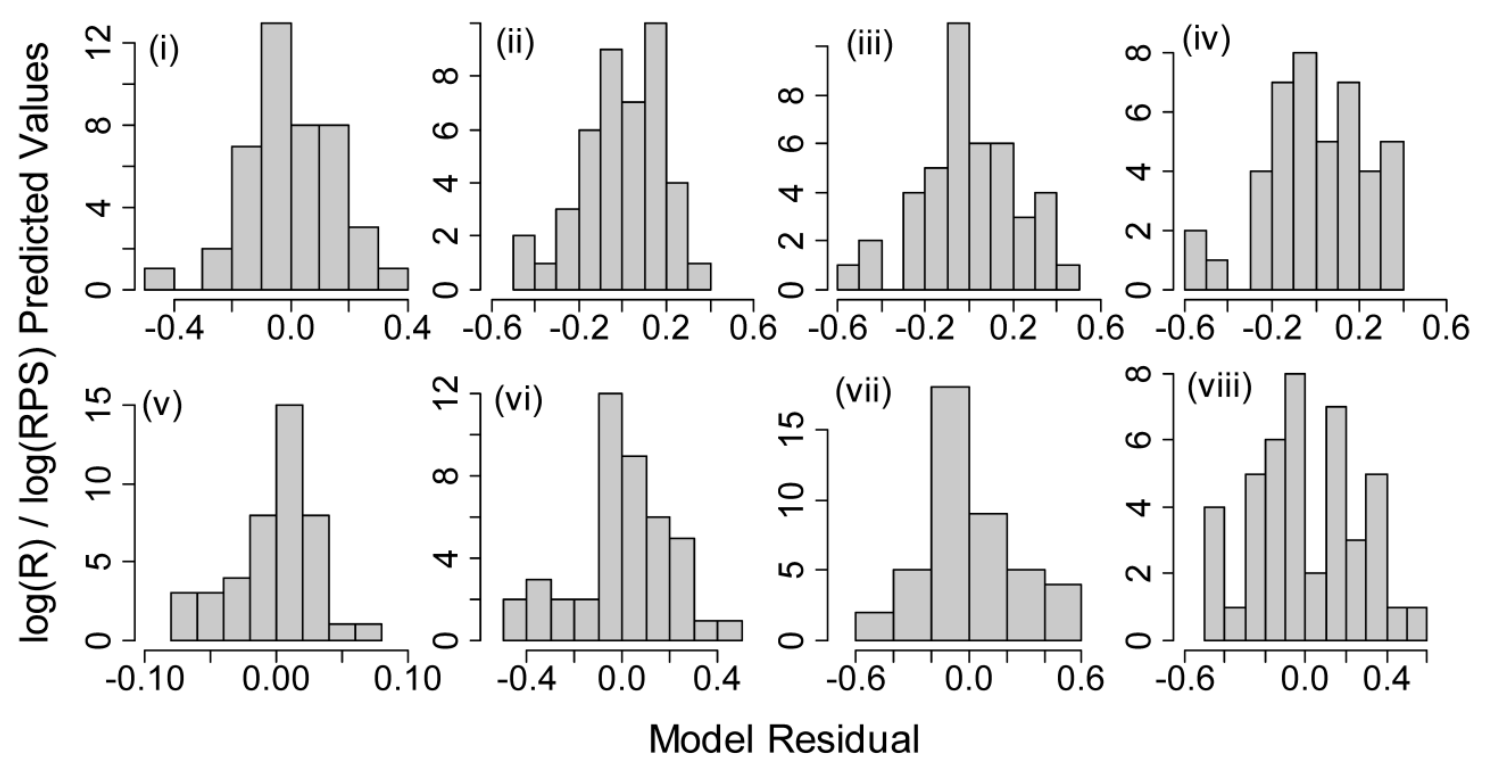

Figure 9. Histograms of model residuals from Table 2 against the predicted values. The roman numerals refer to the model numbers in Table 2. The residual variance model (i) for recruitment $(R)$ and model $(v)$ for recruits per spawning biomass $(R P S)$ are $<0.9$ and $<1.2$ respectively. The residual variance for models incorporating multiple environmental variables (model $i$ and $v$ ) are smaller compared to models with single environmental variable.

According to Fig. 3 and Table 2 the principle independent variable that has the most significant effect on the North Pacific albacore tuna R and RPS trajectory is the SST. Fig. 10 shows the heat maps for the spatial distribution of the annual SST from the year 1970 to 2012. Visual changes in annual spatial SST can be observed including part of the warm pool (represented in purple and white) which can be observed to change annually.

It should be noted that the standard deviation ( \pm SD) for albacore SSB and R from 2014 ISC report was 97,569 \pm 30,203 $\mathrm{mt}$ for 1993 and 204,401 $\pm 73,551 \mathrm{mt}$ for the year 1971 for SSB. For R the SD was $21.8 \pm 7.4$ million fish for 1987 and $64.6 \pm 18.8$ million fish for the year 1971 (ISC, 2014). Most annual deviations were quite significant, however this was the best available estimate for the South Pacific albacore tuna from 1970 to 2012 and the models presented are based on these estimates. 

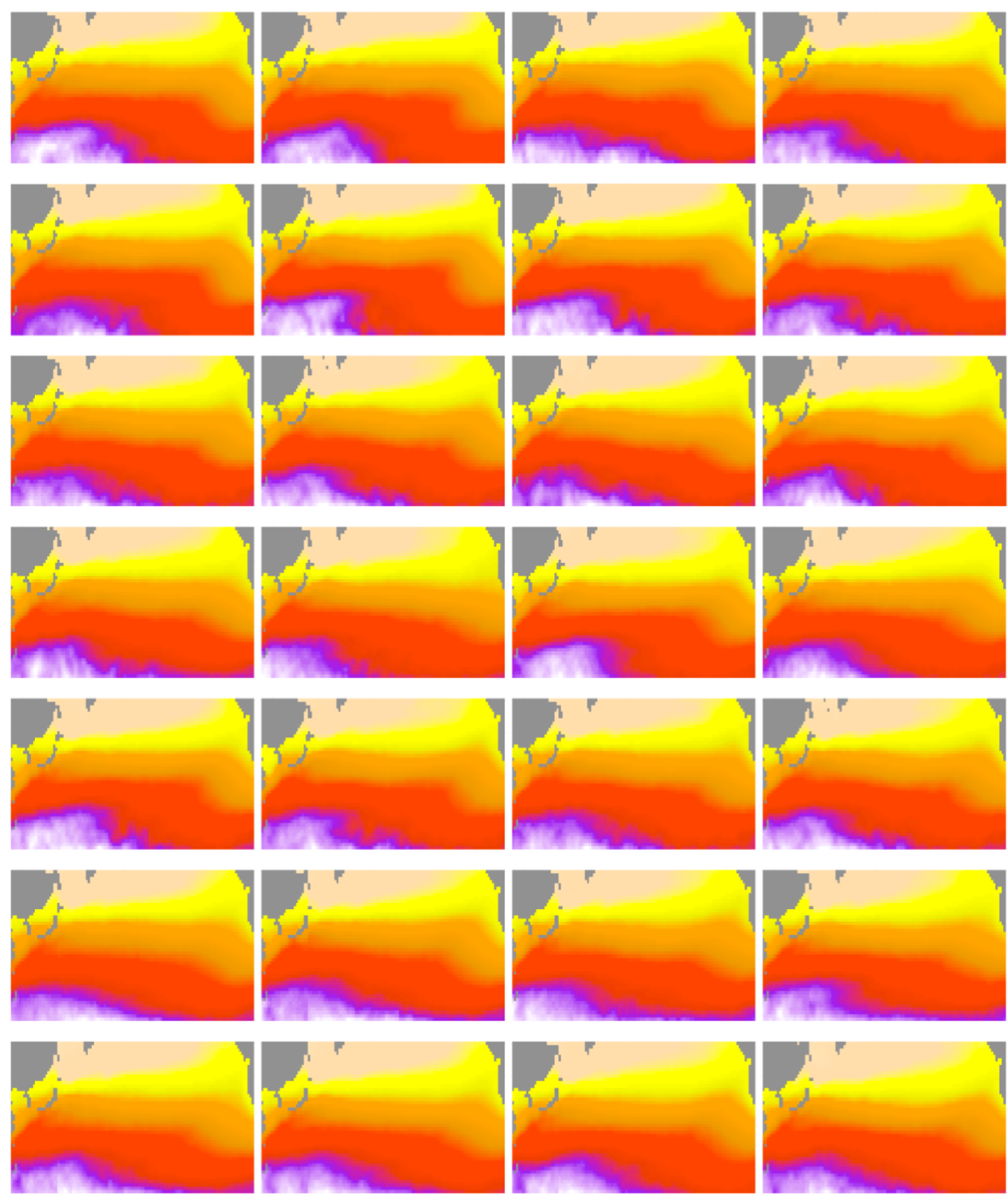

$\mathrm{SST}\left({ }^{\circ} \mathrm{C}\right)$

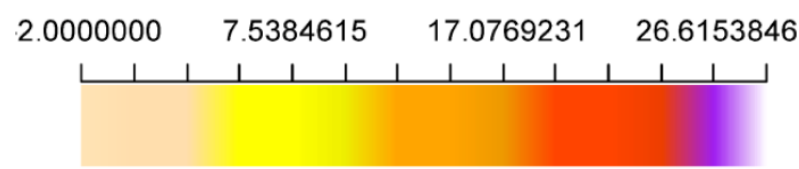

Figure 10. Sea surface temperature (SST) of study area in the North Pacific from 1970 to 2012 from top left to right. The region in purple and white belong to the warm pool where the sea surface temperature is higher than the rest of the geographical oceanic area and seems to fluctuate through the years. Note that the warm pool area coincides with the spawning area for North Pacific albacore shown in Figure 1. The axis labels for latitude, longitude and scales have been removed for enhanced visual representation. Refer to Fig. 1 for study area details. 

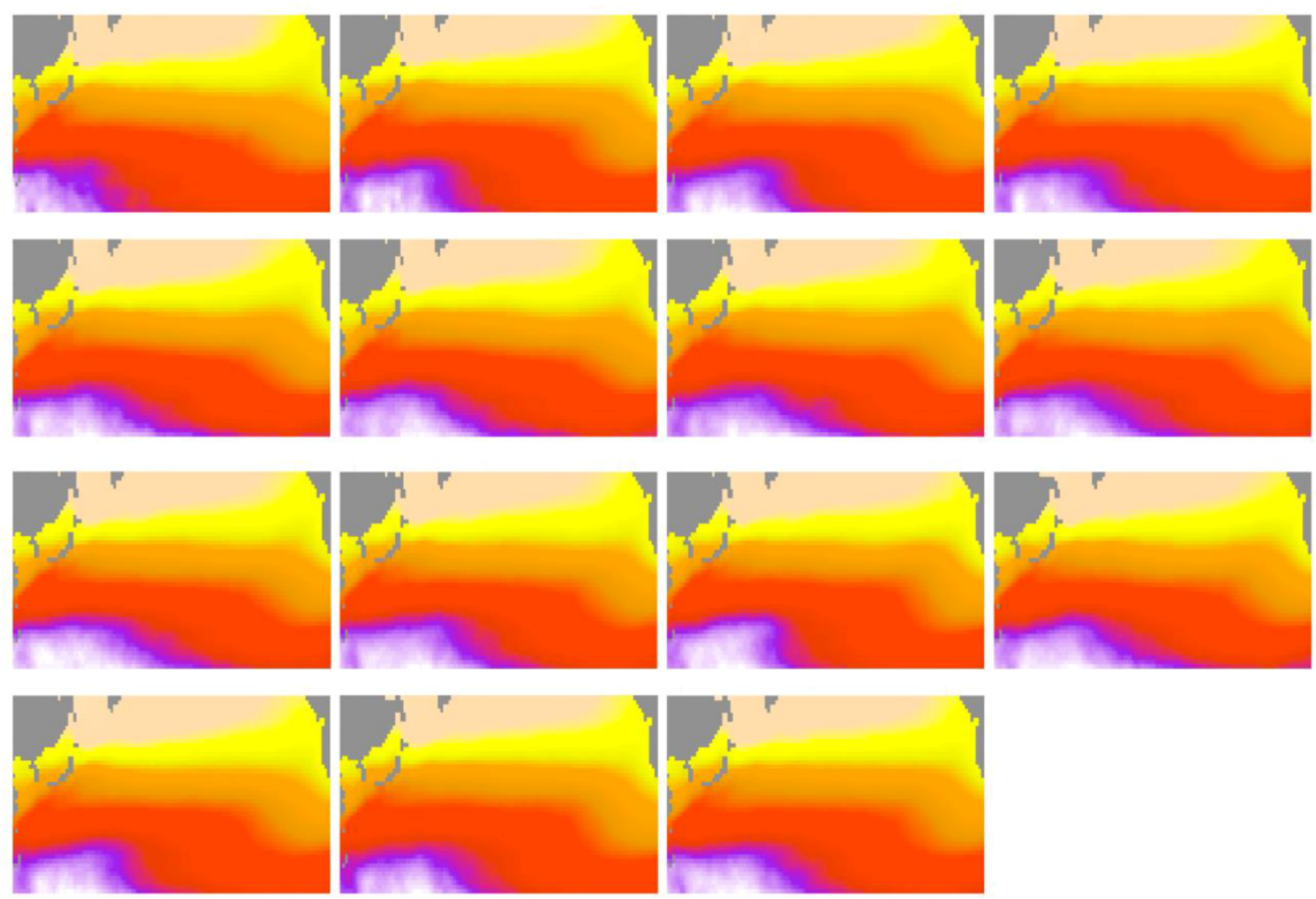

$\mathrm{SST}\left({ }^{\circ} \mathrm{C}\right)$

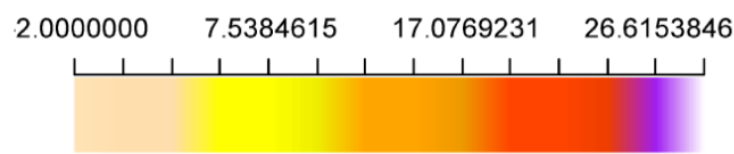

Figure 10. (Cont.)

\section{Discussion}

This work was undertaken with one of the objectives to identify whether alterations in environmental and climatic conditions affected the stock dynamics of the North Pacific albacore tuna. Significant relationships were detected between the albacore tuna R, RPS and SSB with the environmental variables of SST, PDO and ENSO. GAM modeling (Equation 3 and Equation 4) resulted in better fitting of models compared to GLM models (Equation 1 and Equation 2) and the selected models (model (i) and (v), Table 2) for most significantly explaining R and RPS trend were GAM models. This is consistent with the findings that GAM performs better than other types of population modeling (Drexler and Ainsworth, 2013; Moisen and Frescino, 2002; Guisan et al., 2002; Walsh and Kleiber, 2001).

The incorporation of SST and PDO resulted in stock reproduction models for the albacore tuna R and RPS which fit quite well with the referred R and RPS stock trajectory (Table 2, Fig. 5). R exhibited highest correlation with PDO and RPS had most significant correlation with SST. However, when modeling was performed using single variables (Table 2, Fig. 6, Fig. 7), SST resulted in the stock reproduction models with highest fitness for both R and RPS. With reference to the combined and individual effects of the predictor environmental variables (Table 2) it is evident that SST is the principle factor affecting the R and RPS time-series of albacore and the North Pacific 
SST and PDO act together to result in the stock dynamics pattern for the North Pacific albacore tuna R and RPS.

The importance of SST in structuring the stock characteristics of albacore tuna has been shown in previous work. Briand et al. (2011) used the GLM to investigate the links between environmental conditions and albacore tuna in New Caledonia EEZ. Findings showed that albacore CPUE was significantly linked to the variability in SST and primary productivity. Lehodey et al. (2015) investigated the impacts of environmental conditions on the spatial dynamics of albacore tuna in the South Pacific. Findings indicated possibly large impact of changes in oceanic temperature on larval survival and early life stages of albacore. The link between SST affecting dissolved oxygen levels and primary productivity was also established. This gives some indication on the possible mechanisms on how oceanic temperature affects albacore tuna stock abundance and distribution. Dragon et al. (2015) used the Spatial Ecosystem and Population Dynamics Model (SEAPODYM) and the maximum likelihood approach to understand the spatial distribution, ecological characteristics and migratory behavior of the North Atlantic albacore tuna in relation to alterations in the environmental patterns. Spawning favorability and foraging behavior of adult fish were shown to be correlated to different oceanic temperature gradients. From the positive fit of SST with R and RPS (models (i), (ii), (v), (vi), Table 2) it can be inferred that warmer temperatures are favorable and cooler temperature are unfavorable for the reproductive success and recruitment of albacore.

The incorporation of PDO results in significant improvement of the models for both $\mathrm{R}$ and RPS as can be seen from Table 2. Singh et al. (2015) investigated the relationship between albacore CPUE and climatic time series using GLM. Significant links were established between PDO and albacore time series trajectory from 1957 to 2008 in the South Pacific Ocean. Phillips et al. (2014) studied the effect of alterations in the SST and large-scale variability in the climatic conditions of PDO and ENSO on the spatial distribution of the juvenile North Pacific albacore tuna CPUE off the US West coast. Significant relationships were determined between the CPUE and the environmental variables. The incorporation of the SST and PDO as independent variables in the threshold Generalized Additive Mixed Models resulted in statistically significant models with the highest $R^{2}$ value of 0.290. Lehodey et al. (2003) attempted to deduce the mechanisms by which alterations in environmental variables affects the stock of important tuna species in the Pacific. Results indicated that albacore tuna recruitment was significantly affected by the negative and positive phases of PDO. PDO had highly significant correlation with $\mathrm{R}$ in the same year and with SSB having a lag period of 5 years. This indicates that variability in the PDO pattern influences the early life stages of the North Pacific albacore tuna. With reference to Figure 3, the relationship of PDO with R and SSB is negative. This means that the negative PDO phase is favorable and positive PDO phase is unfavorable for the larvae and juvenile stages of albacore. Similar explanations have been derived for the South Pacific albacore stock by Lehodey et al. (2003) and Singh et al. (2015).

Although ENSO were excluded from model formulation, it did exhibit significant relationship with albacore tuna R, RPS and SSB according to Fig. 3. Models with single variables incorporating ENSO are significant for both $\mathrm{R}$ and RPS (Table 2). Zhang et al. (2014) used a logistic production model to study the link between changes in climatic indices and albacore productivity and determined significant relationship of the North Pacific albacore tuna productivity with ENSO. 
Briand et al. (2011) elucidated that extreme ENSO events are favorable for local albacore tuna fishery in New Caledonia EEZ.

The warm pool SST area (Fig. 10) extends from the North to the South Pacific and has been shown to also affect the stock trajectory of the South Pacific albacore tuna (Singh et al., 2015). The warm pool geographical area coincides with the spawning ground for the North Pacific albacore tuna (Fig. 1, Fig. 10) as determined by Chen et al. (2010), Yoshida (1968), Otsu and Uchida (1959), Ueyanagi (1957). This makes it ecologically viable for the SSB and RPS to correlate with annual changes in the SST of this area and affect the stock dynamics of albacore tuna. Albacore tuna prefer warmer water temperatures for spawning and larvae habitat (Lehodey et al., 2008; Lehodey et al., 2015) which occurs at the warm pool zone (Fig. 10). Dragon et al., (2015) identified that the maximum spawning for the North Atlantic albacore tuna occurs at SST of $25.77^{\circ} \mathrm{C}$ with a standard error of $1.74^{\circ} \mathrm{C}$. With reference to Fig. 10 , this temperature falls within the temperature range at the warm pool which is further evidence of variability in the SST affecting the spawning and other stock characteristics of albacore tuna. Further work on the specific warmpool area and its influence on the South Pacific albacore tuna is needed to quantify its effect.

Lehodey et al., (2015) showed that both fishing and environmental conditions significantly affect the abundance of albacore tuna in the South Pacific. Albacore tuna fishery managers and policy makers need to take into account the effects of environmental conditions when formulating their stock harvest plans and management strategies in order for the biological and economical sustainability of this commercially important but limited resource.

The GAM models developed in this study (model (i) and (v), Table 2) were highly significant with reference to the $p$-values. These models were able to explain a substantial component of the y-axis variation for R and RPS trend from 1970 to 2012. With reference to the $R^{2}$ values, there are still considerable portion of the variation that is not explained. It is dangerous to assume that environmental and climatic variables are the only factors affecting the North Pacific albacore stock trajectory. Other variables, such as fishing intensity (effort) and various biotic and abiotic factors are also responsible for stock variation. For fishery management it is also dangerous to assume that fishing related activities are the only factors affecting a fish stock. Fish stock levels are determined by a combination of complex interactions between, fishing related activities, environment change, climatic variation and various biotic and abiotic factors. Further research is needed in order to elucidate the underlying mechanism by which environmental conditions interact with other factors to influence albacore tuna stock abundance and distribution in order to develop coherent policies for fisheries management.

The models presented here and the arguments are based on the estimates of the 2014 ISC report where significant deviation was noted for R and SSB data. Better estimates in the future will enable further improvement of the models and analysis.

Acknowledgements. The authors acknowledge the efforts of the primary data collectors and the stock assessment team of the International Scientific Committee for Tuna and Tuna-like Species in the North Pacific Ocean for providing analysis of primary data for the North Pacific albacore tuna which made this work possible. We also acknowledge the past and present team at the Hadley Centre of the United Kingdom and the National Oceanic and Atmospheric Administration for compiling time series data for environmental and climatic conditions. The University Research and Publication Committee (URPC) of the Fiji National University provided funding for this study, their contributions are acknowledged. 


\section{REFERENCES}

[1] Akaike, H. (1981): Likelihood of a model and information criteria. - Journal of Econometrics 16(1): 3-14. http://dx.doi.org/10.1016/0304-4076(81)90071-3

[2] Bell, J.D., Kronen, M., Vunisea, A., Nash, W.J., Keeble, G., Demmke, A., Pontifex, S., Andréfouët, S. (2009): Planning the use of fish for food security in the Pacific. - Marine Policy 33(1): 64-76. http://dx.doi.org/10.1016/j.marpol.2008.04.002

[3] Bell, J.D., Reid, C., Batty, M.J., Lehodey, P., Rodwell, L., Hobday, A.J., Johnson, J.E., Demmke, A. (2013): Effects of climate change on oceanic fisheries in the tropical Pacific: Implications for economic development and food security. - Climatic Change 119(1): 199-212. http://dx.doi.org/10.1007/s10584-012-0606-2

[4] Briand, K., Molony, B., Lehodey, P. (2011): A study on the variability of albacore (Thunnus alalunga) longline catch rates in the Southwest Pacific Ocean. - Fisheries Oceanography 20(6): 517-529.http://dx.doi.org/10.1111/j.1365-2419.2011.00599.x

[5] Brodziak, J., Mangel, M. (2011) Probable values of stock-recruitment steepness for North Pacific striped marlin. - In: ISC workin paper ISC/11/BILLWG-2/11.

[6] Cahuin, S.M., Cubillos, L.A., Ñiquen, M., Escribano, R. (2009): Climatic regimes and the recruitment rate of anchoveta, Engraulis ringens, off Peru. - Estuarine, Coastal and Shelf Science 84(4): 591-597. http://dx.doi.org/10.1016/j.ecss.2009.07.027

[7] Chhak, K.C., Di Lorenzo, E., Schneider, N., Cummins, P.F. (2009): Forcing of lowfrequency ocean variability in the Northeast Pacific. - Journal of Climate 22(5): 12551276. http://dx.doi.org/10.1175/2008JCLI2639.1

[8] Chen, D.G.D. (2011): CIE review report for albacore tuna assessment review. ISC/12/PLENARY/INFO/14 Review.

[9] Chen, K.S., Crone, P.R., Hsu, C.C. (2010): Reproductive biology of albacore Thunnus alalunga. Journal of Fish Biology 77(1): 119-136. http://dx.doi.org/10.1111/j.10958649.2010.02662.x

[10] Chen, K.S., Shimose, T., Tanabe, T., Chen, C.Y., Hsu, C.C. (2012): Age and growth of albacore Thunnus alalunga in the North Pacific Ocean. - Journal of Fish Biology 80(6): 2328-2344. http://dx.doi.org/10.1111/j.1095-8649.2012.03292.x

[11] Childers, J., Snyder, S., Kohin, S. (2011): Migration ans behavior of juvenile North Pacific albacore (Thunnus alalunga). - Fisheries Oceanography 20(3): 157-173. http://dx.doi.org/10.1111/j.1365-2419.2011.00575.x

[12] Chow, S., Ushiama, H. (1995): Global population structure of albacore (Thunnus alalunga) inferred by RFLP analysis of the mitochondrial ATPase gene. - Marine Biology 123(1): 39-45. http://dx.doi.org/10.1007/BF00350321

[13] Cordue, P.L. (2011): Review of the 2011 North Pacific Ocean albacore tuna stock assessment. - ISC/12/PLENARY/INFO/16 Review.

[14] Cosgrove, R., Arregui, I., Arrizabalaga, H., Goni, N., Sheridan, M. (2014): New insights to behavior of North Atlantic albacore tuna (Thunnus alalunga) observed with pop-up satellite archival tags. - Fisheries Research 150: 89-99.

http://dx.doi.org/10.1016/j.fishres.2013.10.013

[15] Deser, C., Phillips, A.S., Hurrell, J.W. (2004): Pacific interdecadal climate variability: linkages between the tropics and the North Pacific during boreal winter since 1900. Journal of Climate 17(16): 3109-3124. http://dx.doi.org/10.1175/15200442(2004)017\%3C3109:PICVLB\%3E2.0.CO;2

[16] Dickey, D.A., Fuller, W.A. (1979): Distribution of the estimators for autoregressive time series with a unit root. - Journal of American Statistical Association 74(366a): 427-431. http://dx.doi.org/10.2307/2286348

[17] Dragon, A.C., Senina, I., Titaud, O., Calmettes, B., Conchon, A., Arrizabalaga, H., Lehohey, P. (2015): An ecosystem-driven model for spatial dynamics and stockassessment of North Atlantic albacore. - Canadian Journal of Fisheries and Aquatic Sciences 72(6): 1-15. http://dx.doi.org/10.1139/cjfas-2014-0338 
[18] Drexler, M., Ainsworth, C.H. (2013): Generalized additive models used to predict species abundance in the Gulf of Mexico: An ecosystem modeling tool. - PLoS one 8(5): e64458. http://dx.doi.org/10.1371/journal.pone.0064458

[19] Farley, J.H., Hoyle, S.D., Eveson, J.P., Williams, A.J., Davies, C.R., Nicol, S.J. (2014): Maturity ogives for South Pacific albacore tuna (Thunnus alalunga) that account for spatial and seasonal variation in the distributions of mature and immature fish. - PLoS one 9(1): e83017. http://dx.doi.org/10.1371/journal.pone.0083017

[20] Fox, J. (2008): Applied regression analysis and generalized linear models, second Ed. Sage Publications, California.

[21] Ganachaud, A., Gupta, A.S., Brown, J.N., Evans, K., Maes, C., Muir, L.C., Graham, F.S. (2013): Projected changes in the tropical Pacific Ocean of importance to tuna fisheries. Climatic Change 119(1): 163-179. http://dx.doi.org/10.1007/s10584-012-0631-1

[22] Ganachaud, A., Gupta, A.S., Orr, J.C., Wijffels, S.E., Ridgway, K.R., Hemer, M.A., Maes, C., Steinberg, C.R., Tribollet, A.D., Qiu, B., Kruger, J.C. (2011): Observed and expected changes in the tropical Pacific Ocean. - In: Bell, J.D., Johnson, J.E., Hobday, A.J. (ed.), Vulnerability of tropical Pacific fisheries and aquaculture to climate change (pp.101-187), Secretariat of the Pacific Community, Noumea.

[23] Gillett, R. (2009): Fisheries in the economics of Pacific island countries and territories. Pacific Studies Series, Asian Development Bank, Manila.

[24] Guisan, A., Edwards, T.C., Hatsie, T. (2002): Generalized linear and generalized additive models in studies of species distributions: Setting the scene. - Ecological Modelling 157(2): 89-100. http://dx.doi.org/10.1016/s0304-3800(02)00204-1

[25] Hatsie, T., Tibshirani, R. (1986): Generalized additive models. - Statistical Science 1: 297-310. http://dx.doi.org/10.1214/ss/1177013604

[26] Ichinokawa, M., Coan Jr., A.L., Takeuchi, Y. (2008): Transoceanic migration rates of young North Pacific albacore, Thunnus alalunga, from conventional tagging data. Canadian Journal of Fisheries and Aquatic Sciences 65(8): 1681-1691. http://dx.doi.org/10.1139/F08-095

[27] International Scientific Committee (ISC). (2011): Stock assessment of albacore tuna in the North Pacific Ocean in 2011. - In: Report of the Albacore Working Group Stock Assessment Workshop, International Scientific Committee for Tuna and Tuna-like Species in the North Pacific Ocean. Shizuoka, Japan, 4-11 June, 2011.

[28] International Scientific Committee (ISC). (2014): Stock assessment of albacore tuna in the North Pacific Ocean in 2014. - In: Report of the Albacore Working Group. International Scientific Committee for Tuna and Tuna-like Species in the North Pacific Ocean. Taipei, Taiwan, 16-21 July 2014.

[29] Iwata, S., Sugimoto, H., Takeuchi, Y. (2011): Calculation of the steepness for the North Pacific albacore. Shimizu, Shizuoka, Japan, 30 May - 11 June, 2011. ISC/11/ALBWG/18.

[30] Kwiatkowski, D., Phillips, P.C.B., Schmidt, P., Shin, Y. (1992): Testing the null hypothesis of stationarity against the alternative of a unit root. - Journal of Econometrics 54 (1-3): 159-178. http://dx.doi.org/10.1016/0304-4076(92)90104-Y

[31] Laurs, R.M., Fiedler, P.C., Montgomery, D.R. (1984): Albacore tuna catch distributions relative to environmental features observed from satellites. - Deep Sea Research Part A. Oceanographic Research Papers 31(9): 1085-1099. http://dx.doi.org/10.1016/0198-0149(84)90014-1

[32] Le Borgne, R., Allain, V., Griffiths, S.P., Matear, R.J., McKinnon, A.D., Richardson, A.J., Young, J.W. (2011): Vulnerability of open ocean food webs in the tropical Pacific to climate change. - In: Bell, J.D., Johnson, J.E., Hobday, A.J., (ed.), Vulnerability of tropical Pacific fisheries and aquaculture to climate change, Secretariat of the Pacific Community, Noumea, 189-249.

[33] Lehodey, P., Chai, F. Hampton, J. (2003): Modelling climate-related variability of tuna populations from a coupled ocean-biogeochemical-populations dynamics model. - 
Fisheries Oceanography 12(4-5): 483-494. http://dx.doi.org/10.1046/j.13652419.2003.00244.x

[34] Lehodey, P., Senina, I., Murtugudde, R., (2008): A spatial ecosystem and population dynamics model (SEAPODYM)-Modeling of tuna and tuna-like populations. - Progress in Oceanography 78(4): 304-318. http://dx.doi.org/10.1016/j.pocean.2008.06.004

[35] Lehodey, P., Hampton, J., Brill, R.W., Nicol, S., Senina, I., Calmettes, B., Portner, H.O., Bopp, L., Ilyina, T., Bell, J.D., Sibert, J. (2011): Vulnerability of oceanic fisheries in the tropical Pacific to climate change. - In: Bell, J.D., Jhonson, J.E., Hobday, A.J. (ed.) Vulnerability of tropical pacific fisheries and aquaculture to climate change. Secretariat of the Pacific Community, Noumea, 435-484.

[36] Lehodey, P., Senina, I., Nicol, S., Hampton, J. (2015): Modelling the impacts of climate change on South Pacific albacore tuna. - Deep Sea Research Part II: Tropical Studies in Oceanography 113: 246-259. http://dx.doi.org/10.1016/j.dsr2.2014.10.028

[37] Linsley, B.K., Wu, H.C., Dassié, E.P., Schrag, D.P. (2015): Decadal changes in South Pacific sea surface temperature and the relationship to the pacific decadal oscillation and upper ocean heat content. Geophysical Research Letters 42(7): 2358-2366. http://dx.doi.org/10.1002/2015GL063045

[38] MacKinnon, J.G. (1996): Numerical distribution functions for unit root and cointegration tests. - Journal of Applied Econometrics 11: 601-618. http://dx.doi.org/10.1002/(SICI)1099-1255(199611)11:6\%3C601::AID JAE417\%3E3.0.CO;2-T

[39] Mantua, N.J., Hare, S.R., Zhang, Y., Wallace, J.M., Francis, R.C. (1997): A Pacific interdecadal climate oscillation with impacts on salmon production. - Bulletin of the american Meteorological Society 78(6): 1069-1079. http://dx.doi.org/10.1175/15200477(1997)078\%3C1069:APICOW\%3E2.0.CO;2

[40] Moisen, G.C., Frescino, T.S. (2002): Comparing five modelling techniques for predicting forest characteristics. - Ecological Modelling 157(2): 209-225. http://dx.doi.org/10.1016/S0304-3800(02)00197-7

[41] Nieto, K., Xu, Y., Teo, S.L.H., McClatchie, S., Holmes, J. (2015): How important are coastal fronts to albacore tuna (Thunnus alalunga) habitat in the Northeast Pacific Ocean? - Progress in Oceanography. In Press. http://dx.doi.org/10.1016/j.pocean.2015.05.004

[42] Otsu, T., Uchida, R.N. (1959): Sexual maturity and spawning of albacore in the Pacific Ocean. - Fishery Bulletin of the Fish and Wildlife Service 50: 287-305.

[43] Pearcy, W.G. (1973): Albacore oceanograpy off Oregon: 1970. - Fishery Bulletin 71(2): 489-514.

[44] Phillips, A.J., Ciannelli, L., Brodeur, R.D., Pearcy, W.G., Childers, J. (2014): Spatiotemporal associations of albacore CPUEs in the Northeastern Pacific with regional SST and climate environmental variables. - ICES Journal of Marine Science: Journal du Conseil 71(7): 1717-1727. http://dx.doi.org/10.1093/icesjms/fst238

[45] R Core Team. (2014): R: A language and environment for statistical computing. R Foundation for Statistical Computing, Vienna, Austria. URL http://www.r-project.org/

[46] Ramon, D., Bailey, K. (1996): Spawning seasonality of albacore, Thunnus alalunga, in the South Pacific Ocean. - Fishery Bulletin 94(4): 725-733.

[47] Rayner, N.A., Parker, D.E., Horton, E.B., Folland, C.K., Alexander, L.V., Rowell, D.P., Kent, E.C., Kaplan, A. (2003): Global analysis of sea surface temperature, sea ice and night marine air temperature since the late nineteenth century. - Journal of Geophysical Research 108(D14). http://dx.doi.org/10.1029/2002JD002670

[48] Sakuramoto, K. (2013): A recruitment forecasting model for the Pacific stock of the Japanese sardine (Sardinops melanostictus) that does not assume density-dependent effects. - Agricultural Sciences 4(6A): 1-8. http://dx.doi.org/10.4236/as.2013.46A001

[49] Singh, A. A., Sakuramoto, K., Suzuki, N. (2014): Model for stock-recruitment dynamics of the Peruvian anchoveta (Engraulis ringens) off Peru. - Agricultural Sciences 5(2): 140151. http://dx.doi.org/10.4236/as.2014.52017 
[50] Sakuramoto, K. (2016): Case study: A simulation model of the spawning stock biomass of Pacific Bluefin tuna and evaluation of fisheries regulations. - American Journal of Climate Change 5: 245-260. http://dx.doi.org/10.4236/ajcc.2016.52021

[51] Singh, A.A., Sakuramoto, K., Suzuki, N. (2015): Impact of climatic factors on albacore tuna (Thunnus alalunga) in the South Pacific Ocean. - American Journal of Climate Change 4(04): 295-312. http://dx.doi.org/10.4236/ajcc.2015.44024

[52] SPC. (2012): Oceanic fisheries and climate change. Secretariat of the Pacific Community. Policy Brief. No. 15/2012.

[53] Suzuki, Z., Warashina, Y., Kishida, M. (1977): The comparison of catches by regular and deep tuna longline gears in the Western and Central Equatorial Pacific. - Bulletin-Far Seas Fisheries Research Laboratory 15: 51-89.

[54] Takagi, M., Okamura, T., Chow, S., Taniguchi, N. (2001): Preliminary study of albacore (Thunnus alalunga) stock differentiation inferred from microsatellite DNA analysis. Fishery Bulletin-National Oceanic and Atmospheric Administration 99(4): 697-701.

[55] Ueyanagi, S. (1957): Spawning of the albacore in the Western Pacific. - Report of Nankai Regional Fisheries Research Laboratory 6: 113-124.

[56] Ueyanagi, S. (1969): Observations on the distribution of tuna larvae in the Indo-Pacific Ocean with emphasis on the delineation of the spawning areas of albacore. Thunnus alalunga. - Bulletin-Far Seas Fisheries Research Laboratory 2: 177-256.

[57] Walsh, W., Kleiber, P. (2001): Generalized additive model and regression tree analysis of blue shark (Prionace glauca) by the Hawaii-based longline fishery. - Fisheries Research 53(2): 115-131. http://dx.doi.org/10.1016/S0165-7836(00)00306-4

[58] Wells, R.D., Kohin, S., Teo, S.L., Snodgrass, O.E., Uosaki, K. (2013): Age and growth of North Pacific albacore (Thunnus alalunga): Implications for stock assessment. - Fisheries Research 147: 55-62. http://dx.doi.org/10.1016/j.fishres.2013.05.001

[59] Wolter, K., Timlin, M.S. (1998): Measuring the strength of ENSO events: How does 1997/98 rank? - Weather 53(9): 315-324. http://dx.doi.org/10.1002/j.14778696.1998.tb06408.x

[60] Yoshida, H.O. (1968): Early life history and spawning of the albacore, Thunnus alalunga, in Hawaiian waters. - Fishery Bulletin 67: 205-211.

[61] Zainuddin, M., Saitoh, S.I., Saitoh, K. (2004): Detection of potential fishing ground for albacore tuna using synoptic measurements of ocean color and thermal remote sensing in the Northwestern North Pacific. - Geophysical Research Letters 31(20): L20311. http://dx.doi.org/10.1029/2004gl021000

[62] Zhang, Y., Wallace, J.M., Battisti, D.S. (1997): ENSO-like interdecadal variability: 190093. - Journal of Climate 10(5): 1004-1020. http://dx.doi.org/10.1175/15200442(1997)010\%3C1004:ELIV\%3E2.0.CO;2

[63] Zhang, Z., Holmes, J., Teo, S.L. (2014): A study on relationships between large-scale climate indices and estimates of North Pacific Albacore tuna productivity. - Fisheries Oceanography 23(5): 409-416. http://dx.doi.org/10.1111/fog.12077

[64] Zuur, A.F., Leno, E.N., Elphick, C.S. (2010): A protocol for data exploration to avoid common statistical problems. - Methods in Ecology and Evolution 1(1): 3-14. http://dx.doi.org/10.1111/j.2041-210X.2009.00001.x 